\title{
An Analysis of Impact of Brand Credibility and Perceived Quality on Consumers' Evaluations of Brand Alliance
}

\author{
Seyed Fathollah Amiri Aghdaie (Corresponding author) \\ Assistant Professor, Dep. of management, University of Isfahan \\ HezarJerib, St. Darvazeh Shiraz, Isfahan, Iran \\ Tel: 98-311-793-5251Ｅ-mail: s.aghdaie@ase.ui.ac.ir
}

Hossein Rezaei Dolatabadi

Assistant Professor, Dep. of management, University of Isfahan

Tel: 98-311-793-5206 E-mail: h_rezaei@ase.ui.ac.ir

Vahid Shokri Aliabadi

MBA Candidate, Dep. of management

University of Isfahan, Isfahan, Iran

Tel: 98-913-326-0868Ｅ-mail: ronizv@gmail.com

Received: January 24, 2012 Accepted: February 24, 2012 Published: April 1, 2012

doi:10.5539/ijms.v4n2p93 URL: http://dx.doi.org/10.5539/ijms.v4n2p93

\begin{abstract}
The purpose of this study is to analyse the effects of brand credibility and perceived quality on consumers' evaluation of brand alliance. This goal has been followed by examining the impact of constituent brands credibility on co-brand overall credibility, effect of perceived quality of the constituent brands on co-branded product perceived quality and constituent brands credibility and perceived quality on perceived price and purchase intention of cobranded product as the hypotheses of the study. This study can be considered as an applied research from purpose perspective and descriptive-survey with regards to the nature and method (type of correlation). Respondents to the questionnaire were shoppers at one of branches of Refah chain stores in Isfahan city which randomly selected.

The study indentified that credibility of constituent brands (i.e., brand $A$ and brand $B$ the allied brands) positively affect co-brand credibility, cobranded product perceived price and purchase intention. Results also show that perceived quality of constituent brands affect cobranded product perceived quality and perceived price. Furthermore, only perceived quality of one of constituent brands (brand $B$ ) has positive influence on cobranded product purchase intention whereas the perceived quality of the other brand (brand $B$ ) has no effect.
\end{abstract}

Keywords: Co-branding, Brand alliance, Brand credibility, Perceived quality

\section{Introduction}

Crossing from traditional marketing to modern marketing has put firms and companies in a situation in which traditional marketing strategies cannot handle the highly competitive market environment anymore and in that case competitive advantages cannot easily be achieved. Therefore, firms are looking for new solutions and strategies that allow them not only to increase their market share but also to give them better and more distinctive competitive advantages.

Companies in various industries have to apply nontraditional, innovative branding strategies, such as co-branding because of unstable environments, dynamic markets, intense competition, and high costs to enter new markets (Desai \& Keller, 2002). Co-branding strategy is defined when two brands or more introduce a product jointly to the market or when two or more brands cooperate in marketing activities such as promotion (Rao et al., 1999). Co-branding is a marketing and branding technique which can help firms to compete in the 
dynamic markets. The definition of Co-branding and brand alliance almost is the same, so that in the marketing literature they are used interchangeably.

Nowadays, we can find various examples of brand alliances such as LG-Prada, Samsung-Armani, Google-Samsung and Ferrari-Virtue in the market. Google, a search engine that provides companies and websites with advertising solutions, cooperated with T-Mobile in introducing a first generation cell phone, G1 in August 2008. By this effective strategy, T-Mobile earned 1.5 million preorders (reported by the press) and challenged the iPhone's dominance over cell phone market (Besharat, 2010).

The most important issue in the field of brand alliance is that why and how consumers evaluate brand alliances and co-branded products. In order to improve our understanding of how consumers evaluate co-branded products we need a deeper understanding of the factors affecting this evaluation. This study is trying to investigate the way by which factors like brand credibility and brand perceived quality affect consumers' evaluation of brand alliance. To meet this objective, first, we begin with a review of the literature on co-branding, brand alliance and factors affecting consumers' evaluation. This is followed by an outline of the methodological approach and the results of the study are reported. Finally, the conclusion and managerial implications are discussed.

\section{Co-Branding}

Because there is no consensus about the definition of co-branding among researchers, other terms such as brand alliance, composite branding, ingredient or composite branding, multi-branding, and joint or dual branding are used interchangeably (Besharat, 2010). Generally, co-branding strategy is defined when two brands or more introduce a product jointly to the market or when two or more brands cooperate in marketing activities such as promotion (Rao et al., 1999). Askegaard and Bengtsson (2005) imply that co-branding is a brand strategy which is used in various markets and industries all over the world. Besharat (2010) also suggests three criteria to identify co-branding strategy:

- A long-term agreement and cooperation is necessary to form a co-brand.

- The product's logo or package should present the name of both brands together.

- The primary goal of co-branding is to introduce a new product to the market.

Today, co-branding is a common strategy for introducing new products or the same products but with new features to the market, especially in the electronic and computer market. Partnering of Samsung with Armani (Samsung-Armani) and Google (Samsung-Google, Nexus) to introduce cell phones is a good example of this strategy. By using co-branding strategy, Samsung, Armani, and Google can benefit from each other's advantages, expertise and even market share. However, co-branding is not simply just a combination of two brands or cooperation between them (Motion et al., 2003). Nowadays, co-branding has more complicated concept. Firms that want to form a co-brand may consider value of their brands (Motion et al., 2003) or their brand equity (Besharat, 2010) in order to get better results from their cooperation. Thus, various factors should be considered to form a co-brand because inappropriate implementation of co-branding strategy may result in negative consequences (James, 2005).

Regardless of probable negative results of co-branding strategy, this strategy has undeniable benefits. Besharat (2010) indicates the benefits of co-branding for participating brands. For example, co-branding may make it easy for brands to transfer positive brand associations from one brand to another. Co-branding can serve as quality signals of a new product. Co-branding also influences perceptions about the image of one brand when legitimacy transfers from the second brand. That is, brands that are present in a co-brand can share their values and images with each other. Hadjicharalambous (2001) also indentifies co-branding benefits as follows:

- Co-branding facilitates access to distribution.

- Because of the fit between the core brands and the extension, the probability that consumer evaluates co-branded products would be increased.

- From a signaling standpoint, consumers may be more confident about product quality with a co-branding extension than a single brand extension.

\section{Brand Alliance}

The term of brand alliance refers to a combination of two or more individual brands which may be short-term or long-term (Rao and Ruekert, 1994; Simonin and Ruth, 1998). Rodrigue and Biswas (2004), suggest that brand alliances can be defined as two types: joint promotion and ingredient brand alliance. They suggest that "joint promotion involves the promotion of complementary product use". For example, each of Crest and Oral-B that are promoted together can be consumed independently by consumer. In contrast, "the ingredient brand alliance 
involves an integration of two products such that one product cannot be consumed without consuming the other". A well known example of this kind of alliance is the "Intel Inside" campaign (Rodrigue and Biswas, 2004). Similarly, previous research divide brand alliance into two forms: physical or symbolic (Simonin and Ruth, 1998; Rao et al., 1999; James, 2006). Going along with the previous research, this study uses a set of hypothetical physical alliances in order to test the hypotheses (Simonin and Ruth, 1998; Rao and Ruekert, 1999; James, 2006).

Various studies use signaling theory to explain the rationale behind the brand alliances (Rao et al., 1999; Park et al., 1996; Levin et al., 1996; Simonin and Ruth, 1998; James, 2006). For instance, Rao et al. (1999) suggest that brand alliances may signal unobservable product quality. Moreover, James (2006) suggests that, the value of the alliance can be questioned when low levels of product quality are signaled by the alliance. On the other hand, prior research indicated that consumers' perceptions and attitudes towards each of brands involved in an alliance can influence attitudes towards the brand alliance (Simonin and Ruth, 1998; Rodrigue and Biswas, 2004; James, 2006; Bluemelhuber et al., 2007; Besharat, 2010). Besides considering brand quality as an important factor and market signal, credibility of brand can be considered as another important signal. Thus, consumer's perception about credibility and quality of each of brands which are presented in an alliance may affect attitudes towards the alliance.

\section{Brand Credibility}

According to Erdem and Swait (2004) credibility is the most important attribute of a brand that can signal product positioning. Good warranty, advertising expenditure and brand names can serves as signals of quality (Rao et al., 1999). Similarly, Erdem and Swait (2004) suggest that marketing mix elements (product, price, promotion, and place) as well as brand can be used as signals of product quality. However, what distinct brands from marketing mix elements is that brand names contains the cumulative effect of past marketing mix strategies and activities (Erdem and Swait, 2004). In fact, each brand name may bring a certain level of credibility to consumer's mind.

Brand credibility is "the believability of the product position information embedded in a brand depending on consumers' perceptions of whether the brand has the ability and willingness to continuously deliver what has been promised" (Erdem and Swait, 2004). The two aspects of brand credibility are trustworthiness and expertise (Erdem and Swait, 1998, 2004, Erdem et al., 2002, 2006). Trustworthiness means that whether a firm is willing to deliver what it has promised and expertise means whether a firm is able to meet what is promised (Baek and King, 2011). According to signaling theory, brand credibility also can be used as a market signal. For example, higher credibility may result in higher consumer's evaluations of quality (Wernerfelt, 1988). That is, consumers may evaluate credible brands as high quality brands (Baek and King, 2011). The important issue in the context of brand alliance is that whether credibility of each constituent brand transfers to the alliance.

\section{Perceived Quality}

Zeithaml (1988) defines perceived quality "as the consumer's judgment about a product's overall excellence or superiority". Zeithaml (1988) argues that the quality which is perceived by consumer differ from actual quality. Actual or objective quality usually is measurable and verifiable which is based on the predetermined statndards (Zeithaml, 1988). Rao and Ruekert (1994) also divide quality into objective and subjective. Marketing mix elements such as price, place, or promotion may provide consumers with a series of cues that can be used to evaluate quality of branded products. In line with the signaling theory, various elements related to the brand such as price, country of origin (Yoo et al., 2000), good warranty and advertising expenditure (Rao and ruekert, 1999) can serve as quality signals. As discussed before, brand names also can serve as signals of unobservable quality (Rao and Ruekert, 1999). Therefore, judgments about quality of a brand may be obtained from a direct experience with the brand or just brand names (Rao and Ruekert, 1994).

According to Pappu et al. (2005), perceived quality gives consumers a reason to buy a brand because brands can be differentiated by the perceived quality. Milewicz and Herbig (1994) argue that the higher the perceived quality of the brand is, the higher the evaluations of the brand extension are.

\section{Signaling Theory}

Signaling theory which is based on information asymmetry theory (when each party in a transaction have different information related to the transaction issue) provides a roadmap through which consumers can make judgments about product attributes and/or benefits. Problem of information asymmetry occurs when different levels of information flow between consumers and firms (Baek and King, 2011). When consumers are uncertain about the quality of a product or service, using market signals can be helpful. A signal is defined as "an action 
that the seller can take to convey information credibly about unobservable product quality to the buyer" (Rao et al. 1999). For example, as it mentioned before, advertising expenditure can serve as a signal because such expenditure will be incurred only by honest, high quality firms that can recoup their advertising expenditures from future sales (Rao and Ruekert, 1999). Similarly, Kirmani (1990) suggests that consumers sometimes use their perceptions of advertising expenditures of firms as cues to infer quality when there isn't enough information about product quality.

\section{Background of Research}

Baek and king (2011) in a study, "Exploring the consequences of brand credibility in services", attempt to investigate whether the framework of brand credibility effects can be applied to service categories. They also examine whether brand credibility has the equal effect between different types of service and involvement level brand. Results of the study show that, brand credibility has a strong impact on purchase intention through an increase in perceived quality, perceived value for money, and information costs saved, and through a decrease in perceived risk across multiple service categories. The results also indicate that the extent to which brand credibility affect purchase intention differs between utilitarian and hedonic services.

Besharat (2010) in his study, "How co-branding versus brand extensions drive consumers' evaluations of new products: A brand equity approach", compares the effectiveness of co-branding versus brand extension strategies and examines whether different levels of brand equity have different effects on consumers' attitudes, quality perceptions, and purchase intentions for a new product. Results reveal that, partnering with a high-equity brand can derive consumers' evaluations of a new product. However, the findings of comparison indicate that there are no significant differences between co-branding and brand extensions in terms of consumer evaluations of an identical product.

Lafferty (2007) in a research entitled "The relevance of fit in a cause-brand alliance when consumers evaluate corporate credibility" shows that there is a positive relationship between consumers' perceptions of corporate credibility, attitudes towards the constituent brand, and purchase intentions.

James (2006), in his research, " Extension to alliance: Aaker and Keller's model revisited", revisits the Aaker and Keller's model and framework into the brand extensions. In this study James (2006) tries to apply Aaker and Keller's model and framework to brand alliance by returning to their work. Results show that, the primary objective of study was met. That is, extension framework can be applied to brand alliances. Additionally, findings indicated that there is a direct link and positive relationship between quality of original brand and attitudes towards the brand extension. Findings also have shown that there is a direct and positive relationship between partner brand perceived quality and attitudes towards the brand extension.

Hadjicharalambous (2001) in his research, "Show me your friend and I will tell you who you are: A consumer evaluation of co-branding extensions: using structural equation model", seeks to extend brand extension-brand equity research by examining the phenomenon of co-branding. This study shows that the major effects of fit of each of the constituent brands are indirect. The results also show that quality of constituent brands has a positive direct effect on the consumer's evaluation of the extension. It means that the higher the quality of the core brand, the higher the evaluation of the extension.

\section{Methodology}

\subsection{Pretest}

To determine the appropriate brands in order to form hypothetical co-brand combinations, a pretest was conducted. Five categories (each includes 6 brand names) of brand names (1. Home appliances, 2. Computers and laptops, 3. Cell phones, 4. Sports, and 5. Sunglasses) were tested through a two section questionnaire. The participants $(\mathrm{n}=40)$ whose characteristics were similar to those that would be participating in the main study were instructed to indicate the extent to which they are familiar with the brand names through a series of 5-point likert scales ( $1="$ Not at all familiar", $5=$ "Very familiar") in the first section. Similarly, for the second, they were asked to evaluate the quality of each brand name on a 5-point likert scale ( $1=$ "Low quality", $5=$ "High quality").

Two categories with most degree of familiarity selected through this procedure (Home appliances: Mean=3.483, Std.Deviation= 0.589; Computers and laptops: Mean= 3.15, Std.Deviation=1.149). In the first category two brands, both with the highest familiarity (Samsung: Mean= 4.60, Std.Deviation= 0.632; Sony: Mean= 4.58, Std.Deviation $=0.813$ ), were selected as the core brands (brand A). In the second category also two brands, one high familiar brand (Dell: Mean= 4.32, Std.Deviation= 0.944), and one low familiar brand (Lenovo: Mean= 2.50, Std.Deviation $=1.553$ ) were selected as the partner brands (brand B). Consistent with the previous research 
(Simonin and Ruth, 1998; Bluemelhuber et al., 2007) core brand group familiarity and quality were uniformly high but partner brand group familiarity and quality were variable.

After identifying brand names hypothetical brand alliance combinations were Samsung-Dell, Samsung-Lenovo, Sony-Dell, and Sony-Lenovo (see Table 1.). Next, LED smart TV because of its fit with selected brands was chosen to be the carrier of co-brand names.

\subsection{Main Study}

This study can be considered as an applied research from purpose perspective and descriptive-survey with regards to the nature and method (type of correlation). A self administered questionnaire designed by researchers used to collect required data in order to support or reject hypotheses. All questions were on 5-point likert scale ( $1=$ "Strongly disagree" and $5=$ "Strongly agree"). The purpose of this study is to analyse factors affecting consumers' evaluation of brand alliance. This goal has been followed by examining the impact of constituent brands credibility on co-brand overall credibility, effect of perceived quality of the constituent brands on cobranded product perceived quality and constituent brands credibility and perceived quality on perceived price and purchase intention of cobranded product as the hypotheses of the study. This study was conducted among 189 shoppers (female: $54.5 \%$ and male: $45.5 \%$ ) at one of branches of Refah Chain Stores in Isfahan city, Iran (see Table 2.). Also, this study was done from August, 2010 to January, 2012.

Independent variables in this study are as follows:

- $\quad$ Credibility of brand $A$

- Credibility of brand $B$

- $\quad$ Perceived quality of brand $A$

- $\quad$ Perceived quality of brand $B$

And study's dependent variables are:

- Consumer's evaluation about credibility of co-brand

- Consumer's evaluation about perceived quality of co-branded product

- Consumer's evaluation about perceived price of co-branded product

- Consumer's evaluation about purchase intention of co-branded product

Main study employed a 2 (two high familiar brands, Samsung and Sony) X 2 (a high familiar brand, Dell, and a low familiar brand, Lenovo) between subjects factorial design.

\section{Data Analysis and Results}

In order to test the study's hypotheses a series of multiple regressions were used to analyse the relationships between the predictors (independent variables) and the dependent variables. The hypotheses and results are as follows:

$\boldsymbol{H} \boldsymbol{1}_{a}:$ Credibility of brand $A$ positively affects the consumer's evaluation of co-brand credibility.

$H 1_{b}$ : Credibility of brand $B$ positively affects the consumer's evaluation of co-brand credibility.

Credibility of constituent brands, brand $A$ and brand $B$, were significant at the 0.05 level (see Table 3 .). Thus, $H 1_{a}$ and $H 1_{b}$ are fully supported.

$\boldsymbol{H} \boldsymbol{2}_{a}$ : Perceived quality of brand $A$ positively affects the consumer's evaluation of quality of co-branded product.

$\boldsymbol{H}_{b}$ : Perceived quality of brand $B$ positively affects the consumer's evaluation of quality of co-branded product.

Perceived quality of constituent brands, brand A and brand B, were significant at the level of 0.05 (see Table 4.). Thus, $H 2_{a}$ and $H 2_{b}$ are supported.

$\boldsymbol{H}_{a}$ : Credibility of brand $A$ positively affects the consumer's evaluation of perceived price of co-branded product.

$\boldsymbol{H 3}_{b}$ : Credibility of brand $B$ positively affects the consumer's evaluation of perceived price of co-branded product.

$\boldsymbol{H}_{c}:$ Perceived quality of brand $A$ positively affects the consumer's evaluation of perceived price of co-branded product.

$\boldsymbol{H 3}_{d}:$ Perceived quality of brand $B$ positively affects the consumer's evaluation of perceived price of co-branded product. 
Credibility and perceived quality of constituent brands, brand $A$ and brand $B$, were significant at the 0.05 level (see Tables 5. and 6.). Thus, $H 3_{a}, H 3_{b}, H 3_{c}$, and $H 3_{d}$ are fully supported.

$\boldsymbol{H} 4_{a}$ : Credibility of brand $A$ positively affects the consumer's evaluation of purchase intention of co-branded product.

$\boldsymbol{H} 4_{b}$ : Credibility of brand $B$ positively affects the consumer's evaluation of purchase intention of co-branded product.

$\boldsymbol{H} 4_{c}$ : Perceived quality of brand $A$ positively affects the consumer's evaluation of purchase intention of co-branded product.

$\boldsymbol{H} 4_{d}$ : Perceived quality of brand $B$ positively affects the consumer's evaluation of purchase intention of co-branded product.

Credibility of constituent brands, brand $A$ and brand $B$, and perceived quality of brand $B$ were significant at the 0.05 level, but perceived quality of brand $A$ was insignificant (see Tables 7. And 8.). Thus, $H 4_{a}, H 4_{b}$, and $H 4_{d}$ are fully supported, but $\mathrm{H}_{c}$ is rejected.

\section{Conclusion}

The results showed that $H 1_{a}$ and $H 1_{b}$ are significantly supported. Thus, credibility of constituent brands (brands $A$ and $B$ ) has a positive and direct effect on co-brand credibility. That is, the higher the credibility of constituent brands, the higher the co-brand credibility. Our findings are consistent with the findings from the previous study (Ballester and Espallardo, 2008). According to the standardized regression coefficients, credibility of brand $A$ has more effect on co-brand credibility than brand $B$ does. Results of testing the hypotheses $H 2_{a}$ and $H 2_{b}$ indicate that, perceived quality of brand $A$ and Brand $B$ affect the perceived quality of co-branded product individually and positively. That is, brands with high perceived quality involved in an alliance can result in higher consumer's evaluation of perceived quality of co-branded product. Thus earlier research findings in the case of co-branding (Hadjicharalambous, 2001) are replicated in this study. Moreover, perceived quality of constituent brand B has more effect than constituent brand $A$ on consumer's evaluation of perceived quality of co-branded product. In fact, credibility and perceived quality of brands $(A$ and $B)$ involved in a brand alliance can serve as market signals that help consumer to make judgments about credibility of co-brand and quality of co-branded product.

Results supported the hypotheses $H 3_{a}, H 3_{b}, H 3_{c}$, and $H 3_{d}$. Thus, credibility of each of constituent brands (brand $A$ and brand $B$ ) has a positive and direct effect on the perceived price of the co-branded product. That is, the higher the credibility of constituent brands, the higher the consumer's evaluation of the perceived price of the co-branded product. Our findings are in consistent with previous study's findings (Baek and King, 2011). Grewal et al. (1998) findings also show that, the more positive the brand reputation is, the higher the buyers' expectations about the price would be. In addition, credibility of brand $B$ has more effect on the consumer's evaluation of perceived price of the co-branded product than credibility of brand $A$ does. Results also show that, perceived quality of constituent brands (brand $A$ and brand $B$ ) has a positive and direct effect on the perceived price of the co-branded product. According to the standardized regression coefficients, perceived quality of brand $B$ has more effect than brand $A$ on the perceived price of the co-branded product. According to the signaling theory, credibility and perceived quality of each of constituent brands can perform as signals of co-branded perceived price to be different.

$H 4_{a}$ and $H 4_{b}$ were fully supported which means that credibility of each of constituent brands (brand $A$ and brand $B$ ) has a positive and direct effect on the purchase intention of the co-branded product. That is, brands with high credibility make it easier for consumers to make a decision about purchasing of co-branded products. In fact, credibility of brands involved in an alliance serves as a signal of purchase intention. Our findings are consistent with the findings from the previous study in cause-brand alliance (Lafferty, 2007). Moreover, effect of credibility of brand $B$ is more than effect of brand $A$ on the purchase intention of the co-branded product.

Supporting $H 4_{d}$ and rejecting $H 4_{c}$ by the study's results shows that, only perceived quality of brand $B$ has a positive and direct effect on purchase intention of the co-branded product whereas perceived quality of brand $A$ has no effect at all on the purchase intention of the co-branded product. It means that, the higher the perceived quality of brand $B$, the higher the consumer's evaluation of purchase intention of co-branded product. According to the signaling theory, quality of brand $B$ can be used by consumers as a cue to make a decision about purchasing of a co-branded product. In addition, our findings are consistent with the previous research in the case of single brands (Baek and King, 2011). 


\section{Managerial Implications}

Based on the results and findings, this study identifies the following implications. First, findings imply that credibility of constituent brands affects the consumers' evaluations of overall credibility of co-brand. Thus, managers, especially marketing and brand managers who look for a partner to form a brand alliance should consider the credibility level of the partner brand. If a brand has the high levels of the credibility in the market, it would be desirable to form an alliance with a brand which is more credible or at least is the same. But, if a brand has the low levels of credibility, and looks for a partner brand, it is necessary to form an alliance with a high credible brand because it would experience higher levels of credibility than it had before forming the alliance.

Second, the impact of perceived quality of constituent brands on perceived quality of co-branded product proposes that it is necessary to consider partners which are high quality based on the consumers' opinions in order to form an alliance. Partnering with a high quality brand would enhance the consumers' evaluations of the co-branded product. Based on the findings, each of brands involved in brand alliance has different effect on the evaluation of the co-branded product. Thus, assessment of the perceived quality of each constituent brand would provide managers with valuable information that can be used to develop criteria for choosing and evaluating potential partner brands (Hadjicharalambous, 2001).

Third, when consumers evaluate various branded products, they usually use price as an important criterion. As the previous studies suggest, price can serve as a signal of quality of products (Kotler, 1991; Monroe, 2003). That is, the higher the price of the product, the higher the quality of it. Our findings show that, credibility and perceived quality of constituent brands have a direct and positive effect on perceived price of co-branded product. Thus, higher credibility and perceived quality of brands lead to higher consumer's evaluation of co-branded product price that is, consumer expects co-branded product price to be different from or higher than the same products with a single brand. Keller (2003) argues that, customers tend to pay higher prices for products with well known brands than for products with unknown brands. Therefore, managers should be aware of factors such as credibility and perceived quality of each brand affecting consumers' evaluations of co-branded product price before forming an alliance because findings of this study offer credibility and perceived quality as signals of perceived price.

Finally, based on the study's results, credibility of each of constituent brands affect the consumer's purchase intention of co-branded product. Thus, managers by choosing credible partner brands, provides their customers with the cues that make decision making about purchasing of the co-branded product easier for them. Our findings show that, only perceived quality of brand $B$ has a direct effect on consumer's evaluation of purchase intention. Thus, in order to form a brand alliance, mangers should consider and select a partner brand which is high quality. By doing this, they would enhance the consumers' evaluations of purchase intention of co-branded products.

Generally, managers should consider brand credibility and perceived quality of brand as important factors that can affect the consumers' evaluation of brand alliance. Based on findings of this study, choosing right and appropriate partner brand is essential to secure a successful brand alliance.

\section{References}

Askegaard, S., and Bengtsson, A. (2005). When Hershey met Betty: love, lust and co-branding. Journal of Product \& Brand Management, Vol. 14, No. 5, pp. 322-329. http://dx.doi.org/10.1108/10610420510616359

Baek, T.H., and King, K.W. (2011). Exploring the consequences of brand credibility in services. Journal of Services Marketing, Vol. 25, No. 4, pp. 260-272. http://dx.doi.org/10.1108/08876041111143096

Ballester, E.D., and Espallardo, M.H. (2008). Building online brands through brand alliances in internet. European Journal of Marketing, Vol. 42, No. 9/10, pp. 954-976. http://dx.doi.org/10.1108/03090560810891091

Besharat, A. (2010). How co-branding versus brand extensions drive consumers' evaluations of new products: A brand equity approach. Industrial Marketing Management, Vol. 39, pp. 1240-1249. http://dx.doi.org/10.1016/j.indmarman.2010.02.021

Desai, K. K., and Keller, K. L. (2002). The effects of ingredient branding strategies on host brand extendibility. Journal of Marketing, Vol. 66, No. 1, pp. 73-93. http://dx.doi.org/10.1509/jmkg.66.1.73.18450

Erdem, T., and Swait, J. (1998). Brand equity as a signaling phenomenon. Journal of Consumer Psychology, Vol. 7, No. 2, pp. 131-57. http://dx.doi.org/10.1207/s15327663jcp0702_02

Erdem, T., and Swait, J. (2004). Brand credibility, brand consideration, and choice. Journal of Consumer Research, Vol. 31, No. 1, pp. 191-8. http://dx.doi.org/10.1086/383434 
Erdem, T., Swait, J., and Louviere, J. (2002). The impact of brand credibility on consumer price sensitivity. International Journal of Research in Marketing, Vol. 19, No. 1, pp. 1-19. http://dx.doi.org/10.1016/S0167-8116(01)00048-9

Erdem, T., Swait, J., and Valenzuela, A. (2006). Brands as signals: a cross-country validation study. Journal of Marketing, Vol. 70, No. 1, pp. 34-49. http://dx.doi.org/10.1509/jmkg.2006.70.1.34

Grewal, D., Krishnan, R., Baker, J., \& Borin, N. (1998). The effect of store name, brand name and price discounts on consumers' evaluations and purchase intentions. Journal of Retailing,. Vol. 74, No.3, pp. 331-352. http://dx.doi.org/10.1016/S0022-4359(99)80099-2

Hadjicharalambous, C. (2001). Show me your friend and I will tell you who you are: A consumer evaluation ofco-branding extensions using structural equation modeling. A dissertation for the degree of doctor of philosophy. USA: The City University of New York.

James, D.O. (2005). Guilty through association: brand association transfer to brand alliances. Journal of Consumer Marketing, Vol. 22, Winter, pp. 1-12.

James, D.O. (2006). Extension to alliance: Aaker and Keller's model revisited. Journal of Product \& Brand Management, Vol. 15, No. 1, pp. 15-22. http://dx.doi.org/10.1108/10610420610650846

Keller, K. L. (2003). Strategic brand management: Building, measuring, and managing brand equity. Englewood Cliffs, New Jersey: Prentice Hall.

Kirmani, A. (1990). The effect of perceived advertising costs on brand perceptions. Journal of Consumer Research. Vol. 17, No. 2, pp. 160-71. http://dx.doi.org/10.1086/208546

Kotler, P. (1991). Marketing Management. (7th ed.). Englewood Cliffs, New Jersey: Prentice- Hall.

Lafferty, B. A. (2007). The relevance of fit in a cause-brand alliance when consumers evaluate corporate credibility. Journal of Business Research, Vol. 60, pp. 447-453. http://dx.doi.org/10.1016/j.jbusres.2006.09.030

Levin, A.M., Davis, J.C., and Levin, I.P. (1996). Theoretical and empirical linkages between consumers' responses to different branding strategies. Advances in Consumer Research, Vol. 23, pp. 296-300.

Milewicz, J., and Herbig, P. (1994). Evaluating the Brand Extension Decision Using a Model of Reputation Building. Journal of Product \& Brand Management, Vol. 3, Iss 1, pp.39- 47. http://dx.doi.org/10.1108/10610429410053077

Monroe, Kent B. (2003). Pricing: Making Profitable Decisions (3rd ed.). Boston, MA: McGraw-Hill/Irwin.

Motion, J., Leitch, S., and Brodie, R.J. (2003). Equity in corporate co-branding, the case of adidas and the all blacks. European Journal of Marketing, Vol. 37, No. 7/8, pp. 1080-1094. http://dx.doi.org/10.1108/03090560310477672

Pappu, R., Quester, P.G, and Cooksey, R.W. (2005). Consumer-based brand equity: Improving the measurement- empirical evidence. Journal of Product and Brand Management, Vol. 14, No. 3, pp. 143-154. http://dx.doi.org/10.1108/10610420510601012

Park, C.W., Jun, S. Y., and Shocker, A.D. (1996). Composite branding alliances: An investigation of extension and feedback effects. Journal of Marketing Research, Vol. 33, No. 4, pp. 453-466. http://dx.doi.org/10.2307/3152216

Rao, A. R., Qu, L., and Ruekert, R. W. (1999). Signaling unobservable product quality through a brand ally. Journal of Marketing Research, Vol. 36, pp. 258-268. http://dx.doi.org/10.2307/3152097

Rao, A.R., and Ruekert, R.W. (1994). Brand alliances as signals of product quality. Sloan Management Review, Vol. 36, Fall, pp. 87-97.

Rodrigue, C.S., and Biswas, A. (2004). Brand alliance dependency and exclusivity: an empirical investigation. Journal of Product \& Brand Management, Vol 13, No. 7, pp. 477-487. http://dx.doi.org/10.2307/3152097

Simonin, B.L., and Ruth, J.A. (1998). Is a company known by the company it keeps? Assessing the spillover effects of brand alliances on consumer brand attitudes. Journal of Marketing Research, Vol. 35, February, pp. 30-42. http://dx.doi.org/10.2307/3151928

Wernerfelt, B. (1988). Umbrella Branding as a Signal of New Product Quality: An Example of Signalling by Posting a Bond. Rand Journal of Economics, Vol. 19, Autumn, pp. 458-66. http://dx.doi.org/10.2307/2555667 
Yoo, B., Donthu, N., and Lee, S. (2000). An examination of selected marketing mix elements and brand equity. Journal of the Academy of Marketing Sciences, Vol. 28, No. 2, pp. $195-211$. http://dx.doi.org/10.1177/0092070300282002

Zeithaml, V.A. (1988). Consumer perceptions of price, quality, and value: A means-end model and synthesis of evidence. Journal of Marketing, Vol. 52, No. 3, pp. 2-22. http://dx.doi.org/10.2307/1251446

Table 1. Alliance brand combinations

\begin{tabular}{|c|c|c|}
\hline $\begin{array}{c}\text { Brand } A \\
\text { (the first brand appeared } \\
\text { in the alliance) }\end{array}$ & $\begin{array}{c}\text { Brand } B \\
\text { (the second brand appeared } \\
\text { in the alliance) }\end{array}$ & Alliance brand combinations \\
\hline Samsung & Dell & Samsung-Dell \\
\hline Samsung & Lenovo & Samsung-Lenovo \\
\hline Sony & Dell & Sony-Dell \\
\hline Sony & Lenovo & Sony-Lenovo \\
\hline
\end{tabular}

Table 2. Demographic profile of participants $(n=189)$

\begin{tabular}{|l|c|c|}
\hline Variables & Frequency & Percentage \\
\hline Age & & \\
\hline $20-30$ & 81 & 42.9 \\
\hline $31-40$ & 69 & 36.5 \\
\hline $41-50$ & 34 & 18 \\
\hline $51-60$ & 3 & 1.6 \\
\hline 61 and above & 2 & 1.1 \\
\hline Education & 3 & 1.6 \\
\hline Lower than high school diploma & 33 & 17.5 \\
\hline High school diploma & 31 & 16.4 \\
\hline Associates degree & 89 & 47.1 \\
\hline Bachelor's degree & 33 & 17.5 \\
\hline Master's degree or higher & & \\
\hline
\end{tabular}

Table 3. Regressions of determinants of credibility of co-brand ( 4 items, $\alpha=0.92$ )

\begin{tabular}{|l|c|c|c|c|c|}
\hline Predictor & Items & $\alpha$ & $\beta$ & $t$-value & $p$-value \\
\hline Credibility of brand $A$ & 5 & 0.86 & 0.344 & 5.197 & $0.000 * *$ \\
\hline Credibility of brand $B$ & 5 & 0.91 & 0.312 & 4.727 & $0.000 * *$ \\
\hline
\end{tabular}

Notes: ** Denotes significance at the 0.05 level

Table 4. Regressions of determinants of perceived quality of co-branded product ( 5 items, $\alpha=0.91$ )

\begin{tabular}{|l|c|c|c|c|c|}
\hline Predictor & Items & $\alpha$ & $B$ & $t$-value & $p$-value \\
\hline Perceived quality of brand A & 3 & 0.75 & 0.231 & 3.397 & $0.001 * *$ \\
\hline Perceived quality of brand B & 3 & 0.93 & 0.332 & 4.871 & $0.000 * *$ \\
\hline
\end{tabular}

Notes: ** Denotes significance at the 0.05 level 
Table 5. Regressions of determinants of perceived price of co-branded product (4 items, $\alpha=0.71$ )

\begin{tabular}{|l|c|c|c|c|c|}
\hline Predictor & Items & $\alpha$ & $B$ & $t$-value & $p$-value \\
\hline Credibility of brand $A$ & 5 & 0.86 & 0.184 & 2.63 & $0.009 * *$ \\
\hline Credibility of brand $B$ & 5 & 0.91 & 0.284 & 4.067 & $0.000 * *$ \\
\hline
\end{tabular}

Notes: ** Denotes significance at the 0.05 level

Table 6. Regressions of determinants of perceived price of co-branded product ( 4 items, $\alpha=0.71$ )

\begin{tabular}{|l|c|c|c|c|c|}
\hline \multicolumn{7}{|l|}{} & Items & $\alpha$ & $B$ & $t$-value & $p$-value \\
\hline Predictor & 3 & 0.75 & 0.155 & 2.196 & $0.029 * *$ \\
\hline Perceived quality of brand A & 3 & 0.93 & 0.263 & 3.723 & $0.000 * *$ \\
\hline
\end{tabular}

Notes: ${ }^{* *}$ Denotes significance at the 0.05 level

Table 7. Regressions of determinants of purchase intention of co-branded product ( 3 items, $\alpha=0.81$ )

\begin{tabular}{|l|c|c|c|c|c|}
\hline Predictor & Items & $\alpha$ & $B$ & $t$-value & $p$-value \\
\hline Credibility of brand $A$ & 5 & 0.86 & 0.181 & 2.683 & $0.008 * *$ \\
\hline Credibility of brand $B$ & 5 & 0.91 & 0.372 & 5.500 & $0.000 * *$ \\
\hline
\end{tabular}

Notes: ** Denotes significance at the 0.05 level

Table 8. Regressions of determinants of purchase intention of co-branded product ( 3 items, $\alpha=0.81$ )

\begin{tabular}{|l|c|c|c|c|c|}
\hline Predictor & Items & $\alpha$ & $B$ & $t$-value & $p$-value \\
\hline Perceived quality of brand A & 3 & 0.75 & 0.109 & 2.196 & 0.107 \\
\hline Perceived quality of brand A & 3 & 0.93 & 0.394 & 3.723 & $0.000 * *$ \\
\hline
\end{tabular}

Notes: ** Denotes significance at the 0.05 level 